Hollywood Vault 



\title{
Hollywood Vault
}

Film Libraries before Home Video

\author{
ERIC HOYT
}

\section{甲}

University of California Press

BERKELEY LOS ANGELES LONDON 
University of California Press, one of the most distinguished university presses in the United States, enriches lives around the world by advancing scholarship in the humanities, social sciences, and natural sciences. Its activities are supported by the UC Press Foundation and by philanthropic contributions from individuals and institutions. For more information, visit www.ucpress.edu.

University of California Press

Oakland, California

(C) 2014 by The Regents of the University of California

Library of Congress Cataloging-in-Publication Data

Hoyt, Eric.

Hollywood vault : film libraries before home video / Eric Hoyt.

pages $\mathrm{cm}$.

Includes bibliographical references and index.

ISBN 978-0-520-28263-6 (cloth : alk. paper)

ISBN 978-0-520-28264-3 (pbk. : alk. paper)

ISBN 978-O-520-95857-9 (e-book)

1. Motion pictures-United States-Distribution. 2. Motion picture studios-United States-History -20th century. 3. Motion picture industry-United States-Finance. 4. Motion picture film collections-Economic aspects. I. Title.

PN1995.9.D57H69 2014

$384^{\prime} .840973-\mathrm{dc} 23$

Manufactured in the United States of America

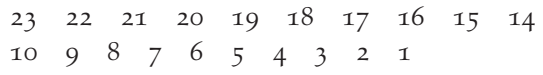

In keeping with a commitment to support environmentally responsible and sustainable printing practices, UC Press has printed this book on Natures Natural, a fiber that contains $30 \%$ post-consumer waste and meets the minimum requirements of ANSI/NISO Z39.48-1992 (R 1997) (Permanence of Paper). 
For Emily, Rumi, and Liam 
